\title{
Trending Speculations of Tumor-Initiating Cells in Squamous Cell Cancers of Head and Neck
}

\author{
Wasim Kamate, Rajendra Baad, Nupura Vibhute, Uzma Belgaumi, Vidya Kadashetti, Sushma Gugwad \\ Department of Oral Pathology and Microbiology, School of Dental Sciences, \\ Krishna Institute of Medical Sciences Deemed University (KIMSDU), Karad, India
}

Tumor-initiating cells are a diminutive subpopulation of stem cells that have ability of long term self-renewal and generation of varied traits of tumor cell population. Understanding the concept of tumor-initiating cells may have a great implicative intimation for our comprehension of cancer pathobiology and for the delineation of new therapies directed towards these stem cells. The present review is an endeavor to conceptualize the role of tumor-initiating cells in the Squamous Cell Cancers (SCC) of head and neck, their role in tumorigenesis and the possible supplementary approach in the latest treatment modalities.

Keywords: Tumor-initiating cells, Squamous cell cancer of head and neck, Malignancy, Undifferentiated cell

The worldwide increment in rate and mortality concerned with Squamous Cell Cancer (SCC) of the Head and Neck has increased endeavors in the field of research relating to tumor science and therapeutics. SCC of the Head and Neck is a standout amongst the most pervasive sorts of danger around the world. The mortality due to SCC of the Head and Neck mostly occurs by local recurrences and cervical lymph node metastasis and infrequently by distant organ metastasis. Various investigations into the malignancy therapeutics have helped in focusing on pathways that seem to contribute to tumorigenesis, and metastasis with more desirable effects and

\footnotetext{
Accepted for publication April 1, 2017, Published online May 30, 2017 Correspondence to Wasim Kamate

Department of Oral Pathology and Microbiology, School of Dental Sciences, Krishna Institute of Medical Sciences Deemed University (KIMSDU), Karad 415110, India

Tel: +02164-241555, Fax: +02164-241584

E-mail: drwasimmds@outlook.com

(c) This is an open-access article distributed under the terms of the Creative Commons Attribution Non-Commercial License (http://creativecommons.org/ licenses/by-nc/4.0/), which permits unrestricted non-commercial use, distribution, and reproduction in any medium, provided the original work is properly cited.

Copyright (c) 2017 by the Korean Society for Stem Cells Research
}

less undesirable side impacts. Tumor-initiating cells have been distinguished in various solid organ malignancies, including Central Nervous System (CNS), pancreas, lung, colon, and lately in SCC of the Head and Neck after their first proposal in leukemic stem cells in the 1990s (1-6).

The generally agreed meaning of a tumor-initiating cell (also known as cancer stem cell) is a cell inside a tumor that has the ability to self-renew and to regenerate new tumors that consist of all clonally-derived cell types present in the parental tumor (7). This review is based on the speculations relating to the stem cells of cancer, specifically the tumor-initiating cell. The genesis of these cells, their part in malignancy progression and metastasis, and conceivable treatment modalities with special reference to SCC of the Head and Neck are highlighted in this review.

Different types of undifferentiated cells develop into the adult stem cells which can later divide into differentiated cells that complete a particular function of the body. It is dubious with reference to whether tumor-initiating cells emerge from undifferentiated cells, adult stem cells, or differentiated cells in an adult tissue. The issue is right now under argument and the speculations in the inception of tumor-initiating cells are displayed as under. 


\section{Speculation no. 1: Tumor-initiating cells emerge from undifferentiated cells}

It has been speculated that the constrained life expectancy of a differentiated cell makes it more averse to live sufficiently long to undergo the multiple changes essential for tumor arrangement and metastasis. In this situation, tumor cells use the existing undifferentiated cell administrative pathways to advance their self-renewability. This ability to self-renew gives undifferentiated cells long life expectancies relative to those of progenitor and differentiated cells $(8,9)$.

\section{Speculation no. 2: Tumor-initiating cells emerge from adult stem cells}

The quantity of adult stem cell is more inexhaustible in a fully developed tissue than are the undifferentiated cells. In spite of this, they hold a partial limit with regards to self-renewal. This property, when considered with their plenitude relative to undifferentiated cells in a fully developed tissue, frames the premise of speculation proposing that adult stem cells are a source of tumor-initiating cells $(10,11)$.

\section{Speculation no. 3: Tumor-initiating cells emerge from differentiated cells}

It is proposed that tumor-initiating cells could emerge from differentiated cells that possibly dedifferentiate to turn into a distinctly more undifferentiated stem cell. In this situation, the imperative oncogenic hereditary changes would need to drive the dedifferentiation step and later ensure the self-renewability of the multiplying cells. This concept leaves open the likelihood that a generally huge populace of cells in the tissue could have tumorigenic potential; a little subset of these would really start the tumor. Particular components to choose which cells would dedifferentiate have not been proposed. Regardless, if a tissue contains an adequate populace of differentiated cells, the laws of likelihood demonstrate that a small portion of them could on a fundamental level, undergo the process necessary for de-differentiation (9). The part of EMT in SCC of the Head and Neck has now been adequately recognized and accepted. Initiation of Epithelialesenchymal Transition (EMT) in differentiated human epithelial cells leads to the acquisition of undifferentiated cell-like phenotype and development of tumor-initiating cells (12-14).

\section{The role of tumor-initiating cells in tumor progression and metastasis}

A traditional concept, called the "the epigenetic progenitor origin of human cancer" characterized malignancy as a proliferative disease outsourcing from transformed tumor cells that contribute to the tumorigenic pursuit of all malignant cells inside a tumor. A large portion of the ideas in carcinogenesis and the treatment of tumor were predicated on such old malignancy concepts. As a result, therefore, it has had the greatest influence on the development of subsisting therapeutic strategies and biochemical malignancy markers so far, but it does not expound some fundamental facts about cancer cells like the diversity observed in a solitary cluster of cancer cells (15). Likewise, the premise of treatment based on this concept has not demonstrated to be useful till now. The stem cell theory of cancer is another characterizing concept for tumorigenesis which considers malignancy as an undifferentiated cell disease. It advocates that malignant undifferentiated cells have a crucial role to play in tumorigenesis (16). Undifferentiated cells at the highest point of their order have the ability to experience self-regeneration and can possibly separate into various sorts of cells in a particular genealogy $(17,18)$. The present concept of tumorigenesis avails to address most of the constraints of traditional malignancy model. Many researchers now consider that stem cell theory of cancer has a role in characterizing the procedure of tumorigenesis. Based on our review of sundry studies, we consider stem cell theory of cancer as more paramount for further discussion of the tumor-initiating cells concept.

The survival of an undifferentiated cell is to a great extent subordinate on the particular and specific "local microenvironment". The local microenvironment is made out of heterogeneous populaces including undifferentiated cells and adjacent differentiated cells that control basic inherent elements important in deciding the fate of undifferentiated cells. These basic elements include the stromal support cells, dissolvable factors, extracellular framework proteins, and blood vessels. The undifferentiated cells in the microenvironment maintain their distinctive stem cell properties like the property of self-renewal and primitiveness $(19,20)$. A comparable kind of microenvironment is essential for the survival of tumor-initiating cells. Factors such as inflammation, EMT, hypoxia, and angiogenesis occurring in tumor-initiating cells microenvironment assists to manage their lethal populace $(20,21)$.

Metastasis is an involute, multistep process that involves a concrete sequence of events; namely, malignant 
cells must escape from the pristine tumor, migrate through the blood or lymph to a contemporary site, adhere to the contemporary site, move from the circulation into the local tissue, form micrometastases, develop a blood supply, and grow to develop an macroscopic and clinically pertinent metastases (22-24). Few scientists have proposed that tumor-initiating cells might be the miniature subsets of malignant cells that drive the spread of disease to the inaccessible organs $(8,25)$. In research based on the observations made in the human colorectal malignancy, an idea of migratory phenotype of cancer stem cells was presented. The sign of this concept is the presence of mobile malignant stem cells, which momentarily creates from stationary malignant stem cells by joining two unequivocal components: the ability to self-renew and differentiate into different tumor cell types and Epithelial-Mesenchymal Transition (EMT). Attributable to the property of mobility, these migratory phenotype of cancer cells can scatter through different entries to favored "local environment" at an inaccessible site which bolsters development and provides sustenance to these relocated cells. Changes in the microenvironment that encompass these cells, for example, inflammation and hormonal status, may later instigate repeated division and differentiation (MesenchymalEpithelial Transition) of dispersed malignant stem cells, prompting to both essential tumor recurrence and metastatic development (26). As of late in view of different molecular research, the idea of migrating cancer stem cell was demonstrated to hold importance even in SCC of Head and Neck (27).

\section{Identification of tumor-initiating cells}

While a large number of studies have distinguished tumor-initiating cells markers over an assortment of solid malignancies, moderately few of these markers have been contemplated in SCC of Head and Neck. We will depict few of the demonstrated strategies by which malignant stem cells in SCC of Head and Neck can be distinguished. By a wide margin, the most well-known technique for recognizing tumor-initiating cells has depended on the increased expression of particular cell surface antigens that improve for cells with malignant stem cells properties. A significant number of these antigens were identified due to their known expression on endogenous stem cells.

\section{CD133}

A transmembrane glycoprotein localized on the cell surface is supposedly the malignant stem cell marker for various epithelial malignancies including colorectal, cere- brum, prostate, breasts and lung (28-31). In SCC of Head and Neck cell lines, CD133 ${ }^{\text {hi }}$ cells display increased clonogenicity, tumorsphere formation and tumorigenicity in xenograft models when compared to their CD133 ${ }^{\text {low }}$ counterparts $(32,33)$.

\section{CD44}

It is a huge malignant stem cell marker that takes part in cell adhesion and migration. It is a known receptor for hyaluronic acid and interfaces with different organic molecules, for example, matrix metalloproteases $(34,35)$. It has been distinguished as a malignant stem cell marker in multiple cancers including the breast and colon cancer (36). Different researchers have now set up the role of CD44 positive cells as a malignant stem cell marker in SCC of Head and Neck (37-39).

\section{Aldehyde Dehydrogenase}

The aldehyde dehydrogenase family (ALDH) is a group of cytosolic isoenzymes which are exceptionally expressed in numerous stem and progenitor cells. ALDH detoxifies intracellular aldehydes through oxidation and probably have a role in the differentiation of stem cells through the oxidation of retinoic acid (40-42). Likewise, with CD44, the lead for researching ALDH as a marker for tumor-initiating cells in SCC of Head and Neck took after recognizable proof in other solid cancers, for example, breasts, colon, liver, and lung tumors (43-46). Numerous research in SCC of Head and Neck have demonstrated the part of ALDH1 + cells in tumorigenesis, metastasis, and chemoresistance in cancers of head and neck (40,41, 47, 48).

\section{ABCB5 expression}

The novel human ATP-binding cassette (ABC) transporter ABCB5 (subfamily B [MDR/TAP] member 5) acts as an energy-dependent drug efflux transporter and marks tumor cells of a putative cancer stem cell compartment. ABCB5 acts as a multifunctional efflux transporter in tumor-initiating cells leading to increased survival and tumor relapse in SCC of Head and Neck. High expression of $\mathrm{ABCB} 5$ can be considered as an independent prognostic factor for CD44 tumor-initiating cells of SCC of Head and Neck (49).

\section{Side population cells}

A specific population of stem cells holding the ability to extrude dye like Hoechst 33342 is referred to as side population cells. Isolation of Hoechst 33342 dye extruding cells from SCC of Head and Neck has revealed that these cells demonstrate the ability to self-renew in-vivo with ad- 
ditional tumorigenic and chemoresistant abilities. Hoechst 33342 dye can be considered as a tumor marker for tumor-initiating cells of SCC of Head and Neck while the cells demonstrating efflux of Hoechst 33342 dye can be identified as tumor-initiating cells (50).

\section{GRP78}

Imperatively, knockdown of GRP78 diminishes self-renewal and tumorigenicity in nude mice recommending that GRP78 is not simply a marker for tumor-initiating cells but also connected to their ability to self-renew and differentiate into different tumor cell types. GRP78 is an endoplasmic reticulum chaperone protein that additionally manifests itself on the cell membrane and is fundamental for the survival of embryonic undifferentiated cells, apparently by acting in the endoplasmic stress reaction pathway. As of late, glucose regulated protein 78 (GRP78) was utilized to recognize tumor-initiating cells from the SCC of Head and Neck cell line. GRP78 is required for tumorigenicity, invasion, and metastasis of SCC of Head and Neck. GRP78 is overexpressed in a few growths including SCC of Head and Neck, and co-expression of the undifferentiated cell marker Nanog with GRP78 is connected with the diminished survival of SCC of Head and Neck patients $(51,52)$.

\section{c-Met}

c-Met was as of late explored as a marker for tumor-initiating cells from the SCC of Head and Neck. It is a tyrosine kinase receptor for hepatocyte growth factor (HGF), is related to metastasis, tumor invasion, and diminished survival. The tumorigenic capability of c-Met + cells at the point, when contrasted with CD44+ cells, was observed to be higher. Additionally, the joined tumorigenic capability of c-Met $+/ \mathrm{CD} 44+$ was observed to be higher when contrasted with individual tumor-initiating cell marker. Conventional chemotherapy resistance present in few malignant tumors has been connected with the stimulated c-Met expression clinically. Henceforth, c-Met expression cannot just be considered as a marker for tumor-initiating cells but additionally as a clinically pertinent remedial focus for a few patients with acquired resistance to chemotherapy. Additional research with a more prominent number of tests to decide tumorigenic capability of c-Met consolidated with different markers like CD44 and ALDH1 is yet to be accomplished (53-55).

\section{Squamospheres}

A squamosphere is a solid, spherical formation developed from the proliferation of one progenitor cell. Cells are grown in the serum-free, non-adherent conditions in order to enrich the progenitor cell population as only progenitor cells can survive and proliferate in this environment. In SCC of Head and Neck, these squamospheres have been shown to be enhanced for stem cell markers, including CK5, OCT4, SOX2, and nestin (56-59).

\section{Treatment modalities targeting tumor-initiating cells of SCC of head and neck}

The current treatment modalities for SCC of Head and Neck are centered on aimless cytoreduction by use of chemotherapy and radiotherapy. Considering the current scenario, tumor-initiating cells provide vital ramifications in regards to the malignancy treatment. The tumor-initiating cell theory proposes that exclusive targeting of tumor-initiating cells will cause the successful elimination of the tumor. In spite of this, there is a considerable proof that tumor-initiating cells have characteristic medication and radiation resistance causing tumor recurrence regardless of the huge decrease in the tumor size. The component behind resistance varies. Radiation resistance is owing to increased DNA repair, while imperviousness to chemotherapy is often times related to drug transport and metabolism, rendering most customary treatments inadequate.

A considerable amount of work is being done to comprehend the molecular mechanisms selective to the pathobiology of tumor-initiating cell, which will permit unique and focused treatment. Considering the role of tumor-initiating cells in tumor progression and metastasis, the treatment modalities for SCC of head and neck might be focused on the inhibition of tumor-initiating cells, promoting the angiogenic inhibitory factors, and enlistment of the tumor-initiating cells towards differentiation and maturation.

Numerous pharmaceutical organizations have formulated medications to focus on the pathways in tumor-initiating cell formation. The capacity of these medications to specifically target tumor-initiating cells while saving normal tissue stays faulty and is basic for the future use of stem cells in cancer treatment. Particular attention on the reactive oxygen species status of tumor-initiating cells is likewise recommended to demonstrate compelling in treatment by modification of intracellular milieu which will encourage programmed cell death over the proliferative effects. Nonetheless, targeting the different transduction pathways required in tumor-initiating cell development like Indent, Wnt, and Hedgehog has given promising outcomes in targeted cancer treatment (60-63). Studies to make tumor-initiating cells chemo-radiosensitive 
have been endeavored in SCC of Head and Neck by means of knockdown of Bmi-1 and CD44. Due consideration should be given to the specificity of drugs used. The drugs that target tumor-initiating cells must stay away from harming normal non-cancerous cells, to be clinically helpful $(48,64)$. The association of tumor-initiating cells with angiogenesis has already been demonstrated. The local microenvironment gives the ability of self-renewal and maintenance, animating fundamental signaling pathways in tumor-initiating cells and prompting to the discharge of elements that advance angiogenesis and development of tumor-initiating cells (65). Henceforth, the part of targeting on angiogenesis in the treatment of carcinomas cannot be disregarded. This is a critical calculated methodology for focused disposal of malignant undifferentiated cells through the interruption of their supportive local microenvironment (66). The consequences of antiangiogenic treatment are entrancing; however, it must be considered with an alert. It has been conceptualized that the malignant cells may procure an invasive phenotype trying to escape from the ominous tumor microenvironment created by the impacts of antiangiogenic medications by means of mechanistic pathways of resistance $(48,67)$. Comparative research in light of differentiating the tumor-initiating cells in SCC of Head and Neck into mature, non-malignant epithelial cells can be attempted by use of their ability of differentiation. Tumor-initiating cell, a type of undifferentiated cell, possesses an inborn veiled limit of differentiation. This process of differentiation is directed by different differentiation elements like bone morphogenetic proteins, which under ordinary conditions incite differentiation of neuron precursors into mature astrocytes (68). In light of the recent updates on the treatment of tumor growth, we propose a multistrategy approach which may demonstrate success instead of customary treatment which has been unsuccessful to improve the morbidity and mortality of head and neck cancer patients. Focusing on tumor-initiating cells shapes the backbone of the proposed multistrategy approach which joins routine treatment which conceivably takes into account cytoreduction and tumor cell initiating therapy which may avert recurrence and metastasis.

\section{Conclusion}

Contemporary advances in sub-atomic procedures have helped in better understanding the part of tumor-initiating cells in cancer progression. Endeavors and further research are still supported to decide particular markers and strategies to explicitly target these cells. With the disturb- ing ascent in a number of new malignancies detected worldwide and reasonable achievement rates of current remedial procedures, another approach in combating tumors which will help diminishing mortality and also bleakness of patient should be critically addressed. We are carefully hopeful about the achievement of tumor-initiating cell targeted therapy which will address the inadequacies of ordinary treatment and will advance as a center methodology in eventual fate of treatment of carcinomas. Research relating to SCC of the Head and Neck stay constrained and a large portion of the speculations depend on cancers from different organs/tissues. More research identifying tumor-initiating cells of SCC of Head and Neck ought to be attempt which will help in the treatment of the malignant disease.

\section{Acknowledgements}

Authors declare no source of funding from the institution for the completion of the review.

\section{Potential conflict of interest}

Authors declare no conflict of interest related to the article.

\section{References}

1. Sawyers CL, Denny CT, Witte ON. Leukemia and the disruption of normal hematopoiesis. Cell 1991;64:337-350

2. Singh SK, Hawkins C, Clarke ID, Squire JA, Bayani J, Hide T, Henkelman RM, Cusimano MD, Dirks PB. Identification of human brain tumour initiating cells. Nature 2004;432:396-401

3. Eramo A, Lotti F, Sette G, Pilozzi E, Biffoni M, Di Virgilio A, Conticello C, Ruco L, Peschle C, De Maria R. Identification and expansion of the tumorigenic lung cancer stem cell population. Cell Death Differ 2008;15:504-514

4. Hermann PC, Huber SL, Herrler T, Aicher A, Ellwart JW, Guba M, Bruns CJ, Heeschen C. Distinct populations of cancer stem cells determine tumor growth and metastatic activity in human pancreatic cancer. Cell Stem Cell 2007; 1:313-323

5. Dalerba P, Dylla SJ, Park IK, Liu R, Wang X, Cho RW, Hoey T, Gurney A, Huang EH, Simeone DM, Shelton AA, Parmiani G, Castelli C, Clarke MF. Phenotypic characterization of human colorectal cancer stem cells. Proc Natl Acad Sci U S A 2007;104:10158-10163

6. Krishnamurthy S, Nör JE. Head and neck cancer stem cells. J Dent Res 2012;91:334-340

7. Wei W, Lewis MT. Identifying and targeting tumor-initiating cells in the treatment of breast cancer. Endocr Relat Cancer 2015;22:R135-R155

8. Goldthwaite CA. Are stem cells involved in cancer. Regenerative Med 2006;9:89-96

9. Gerashchenko TS, Denisov EV, Litviakov NV, Zavyalova 
MV, Vtorushin SV, Tsyganov MM, Perelmuter VM, Cherdyntseva NV. Intratumor heterogeneity: nature and biological significance. Biochemistry (Mosc) 2013;78:1201-1215

10. White AC, Lowry WE. Refining the role for adult stem cells as cancer cells of origin. Trends Cell Biol 2015; 25:11-20

11. Ratajczak MZ, Kucia M, Dobrowolska H, Wanzeck J, Reca R, Ratajczak J. Emerging concept of cancer as a stem cell disorder. Open Life Sciences 2006;1:73-87

12. Polyak K, Weinberg RA. Transitions between epithelial and mesenchymal states: acquisition of malignant and stem cell traits. Nat Rev Cancer 2009;9:265-273

13. Kalluri R, Weinberg RA. The basics of epithelial-mesenchymal transition. J Clin Invest 2009;119:1420-1428

14. Scanlon CS, Van Tubergen EA, Inglehart RC, D'Silva NJ. Biomarkers of epithelial-mesenchymal transition in squamous cell carcinoma. J Dent Res 2013;92:114-121

15. Figueiredo ML, Kim Y, Zhou XC, Myers JN, Wong DD. Molecular mechanisms of head and neck cancer. Drug Discovery Today: Disease Mechanisms 2004;1:273-281

16. Rahman M, Deleyrolle L, Vedam-Mai V, Azari H, Abd-El-Barr M, Reynolds BA. The cancer stem cell hypothesis: failures and pitfalls. Neurosurgery 2011;68:531-545

17. Sell S. Stem cell origin of cancer and differentiation therapy. Crit Rev Oncol Hematol 2004;51:1-28

18. Kondo T. Stem cell-like cancer cells in cancer cell lines. Cancer Biomark 2007;3:245-250

19. Zhang J, Li L. Stem cell niche: microenvironment and beyond. J Biol Chem 2008;283:9499-9503

20. Li L, Neaves WB. Normal stem cells and cancer stem cells: the niche matters. Cancer Res 2006;66:4553-4557

21. Plaks V, Kong N, Werb Z. The cancer stem cell niche: how essential is the niche in regulating stemness of tumor cells? Cell Stem Cell 2015;16:225-238

22. Li F, Tiede B, Massagué J, Kang Y. Beyond tumorigenesis: cancer stem cells in metastasis. Cell Res 2007;17:3-14

23. Hess DA, Allan AL. Migratory strategies of normal and malignant stem cells. Methods Mol Biol 2011;750:25-44

24. Leirós GJ, Balañá ME. Metastatic cancer stem cells: new molecular targets for cancer therapy. Curr Pharm Biotechnol 2011;12:1909-1922

25. Tysnes BB. Tumor-initiating and -propagating cells: cells that we would like to identify and control. Neoplasia 2010; 12:506-515

26. Jung A, Brabletz T, Kirchner T. The migrating cancer stem cells model--a conceptual explanation of malignant tumour progression. Ernst Schering Found Symp Proc 2006;(5): 109-124

27. Smith A, Teknos TN, Pan Q. Epithelial to mesenchymal transition in head and neck squamous cell carcinoma. Oral Oncol 2013;49:287-292

28. Bidlingmaier S, Zhu X, Liu B. The utility and limitations of glycosylated human CD133 epitopes in defining cancer stem cells. J Mol Med (Berl) 2008;86:1025-1032

29. Grosse-Gehling P, Fargeas CA, Dittfeld C, Garbe Y, Alison MR, Corbeil D, Kunz-Schughart LA. CD133 as a bio- marker for putative cancer stem cells in solid tumours: limitations, problems and challenges. J Pathol 2013;229:355378

30. Vander Griend DJ, Karthaus WL, Dalrymple S, Meeker A, DeMarzo AM, Isaacs JT. The role of CD133 in normal human prostate stem cells and malignant cancer-initiating cells. Cancer Res 2008;68:9703-9711

31. Ferrandina G, Petrillo M, Bonanno G, Scambia G. Targeting CD133 antigen in cancer. Expert Opin Ther Targets 2009;13:823-837

32. Monroe MM, Anderson EC, Clayburgh DR, Wong MH. Cancer stem cells in head and neck squamous cell carcinoma. J Oncol 2010;2011.

33. Major AG, Pitty LP, Farah CS. Cancer stem cell markers in head and neck squamous cell carcinoma. Stem Cells Int 2013 doi: 10.1155/2013/319489

34. Knudson WA, Knudson CB. The hyaluronan receptor, CD44. In: Garg H, Hales C, editor. Chemistry and biology of hyaluronan. Oxford: Elsevier; 2004. 83-124.

35. Zhu H, Mitsuhashi N, Klein A, Barsky LW, Weinberg K, Barr ML, Demetriou A, Wu GD. The role of the hyaluronan receptor CD44 in mesenchymal stem cell migration in the extracellular matrix. Stem Cells 2006;24:928-935

36. Basakran NS. CD44 as a potential diagnostic tumor marker. Saudi Med J 2015;36:273-279

37. Athanassiou-Papaefthymiou M, Shkeir O, Kim D, Divi V, Matossian M, Owen JH, Czerwinski MJ, Papagerakis P, McHugh J, Bradford CR, Carey TE, Wolf GT, Prince ME, Papagerakis S. Evaluation of CD44 variant expression in oral, head and neck squamous cell carcinomas using a triple approach and its clinical significance. Int J Immunopathol Pharmacol 2014;27:337-349

38. Chen J, Zhou J, Lu J, Xiong H, Shi X, Gong L. Significance of CD44 expression in head and neck cancer: a systemic review and meta-analysis. BMC Cancer 2014;14:15

39. Faber A, Barth C, Hörmann K, Kassner S, Schultz JD, Sommer U, Stern-Straeter J, Thorn C, Goessler UR. CD44 as a stem cell marker in head and neck squamous cell carcinoma. Oncol Rep 2011;26:321-326

40. Clay MR, Tabor M, Owen JH, Carey TE, Bradford CR, Wolf GT, Wicha MS, Prince ME. Single-marker identification of head and neck squamous cell carcinoma cancer stem cells with aldehyde dehydrogenase. Head Neck 2010;32:1195-1201

41. Chen YC, Chen YW, Hsu HS, Tseng LM, Huang PI, Lu $\mathrm{KH}$, Chen DT, Tai LK, Yung MC, Chang SC, Ku HH, Chiou SH, Lo WL. Aldehyde dehydrogenase 1 is a putative marker for cancer stem cells in head and neck squamous cancer. Biochem Biophys Res Commun 2009;385:307-313

42. Visus C, Ito D, Amoscato A, Maciejewska-Franczak $M$, Abdelsalem A, Dhir R, Shin DM, Donnenberg VS, Whiteside TL, DeLeo AB. Identification of human aldehyde dehydrogenase 1 family member $\mathrm{Al}$ as a novel CD8+ T-cell-defined tumor antigen in squamous cell carcinoma of the head and neck. Cancer Res 2007;67:10538-10545

43. Tomita H, Tanaka K, Tanaka T, Hara A. Aldehyde de- 
hydrogenase $1 \mathrm{Al}$ in stem cells and cancer. Oncotarget 2016;7:11018-11032

44. Rodriguez-Torres M, Allan AL. Aldehyde dehydrogenase as a marker and functional mediator of metastasis in solid tumors. Clin Exp Metastasis 2016;33:97-113

45. Zou B, Sun S, Qi X, Ji P. Aldehyde dehydrogenase activity is a cancer stem cell marker of tongue squamous cell carcinoma. Mol Med Rep 2012;5:1116-1120

46. Allahverdiyev AM, Abamor ES, Bagirova M, Oztel ON, Koc RC, Baydar SY, Elcicek S, Yaman S, Ates SC. Aldehyde dehydrogenase: cancer and stem cells. INTECH Open Access Publisher; 2012.

47. Huang EH, Hynes MJ, Zhang T, Ginestier C, Dontu G, Appelman H, Fields JZ, Wicha MS, Boman BM. Aldehyde dehydrogenase 1 is a marker for normal and malignant human colonic stem cells (SC) and tracks SC overpopulation during colon tumorigenesis. Cancer Res 2009;69:3382-3389

48. Krishnamurthy S, Dong Z, Vodopyanov D, Imai A, Helman JI, Prince ME, Wicha MS, Nör JE. Endothelial cell-initiated signaling promotes the survival and self-renewal of cancer stem cells. Cancer Res 2010;70:9969-9978

49. Grimm M, Krimmel M, Polligkeit J, Alexander D, Munz A, Kluba S, Keutel C, Hoffmann J, Reinert S, Hoefert S. $\mathrm{ABCB} 5$ expression and cancer stem cell hypothesis in oral squamous cell carcinoma. Eur J Cancer 2012;48:3186-3197

50. Zhang P, Zhang Y, Mao L, Zhang Z, Chen W. Side population in oral squamous cell carcinoma possesses tumor stem cell phenotypes. Cancer Lett 2009;277:227-234

51. Wu MJ, Jan CI, Tsay YG, Yu YH, Huang CY, Lin SC, Liu CJ, Chen YS, Lo JF, Yu CC. Elimination of head and neck cancer initiating cells through targeting glucose regulated protein78 signaling. Mol Cancer 2010;9:283

52. Luo S, Mao C, Lee B, Lee AS. GRP78/BiP is required for cell proliferation and protecting the inner cell mass from apoptosis during early mouse embryonic development. Mol Cell Biol 2006;26:5688-5697

53. Sun S, Wang Z. Head neck squamous cell carcinoma c-Met+ cells display cancer stem cell properties and are responsible for cisplatin-resistance and metastasis. Int J Cancer 2011; 129:2337-2348

54. Chen YS, Wang JT, Chang YF, Liu BY, Wang YP, Sun A, Chiang CP. Expression of hepatocyte growth factor and c-met protein is significantly associated with the progression of oral squamous cell carcinoma in Taiwan. J Oral Pathol Med 2004;33:209-217

55. Galeazzi E, Olivero M, Gervasio FC, De Stefani A, Valente G, Comoglio PM, Di Renzo MF, Cortesina G. Detection of MET oncogene/hepatocyte growth factor receptor in lymph node metastases from head and neck squamous cell carcinomas. Eur Arch Otorhinolaryngol 1997;254 Suppl $1: S 138-S 143$
56. Lim YC, Oh SY, Cha YY, Kim SH, Jin X, Kim H. Cancer stem cell traits in squamospheres derived from primary head and neck squamous cell carcinomas. Oral Oncol 2011; 47:83-91

57. Pastrana E, Silva-Vargas V, Doetsch F. Eyes wide open: a critical review of sphere-formation as an assay for stem cells. Cell Stem Cell 2011;8:486-498

58. Chiou SH, Yu CC, Huang CY, Lin SC, Liu CJ, Tsai TH, Chou SH, Chien CS, Ku HH, Lo JF. Positive correlations of Oct-4 and Nanog in oral cancer stem-like cells and high-grade oral squamous cell carcinoma. Clin Cancer Res 2008;14:4085-4095

59. Okamoto A, Chikamatsu K, Sakakura K, Hatsushika K, Takahashi G, Masuyama K. Expansion and characterization of cancer stem-like cells in squamous cell carcinoma of the head and neck. Oral Oncol 2009;45:633-639

60. Pannuti A, Foreman K, Rizzo P, Osipo C, Golde T, Osborne B, Miele L. Targeting Notch to target cancer stem cells. Clin Cancer Res 2010;16:3141-3152

61. Smith J, Ladi E, Mayer-Proschel M, Noble M. Redox state is a central modulator of the balance between self-renewal and differentiation in a dividing glial precursor cell. Proc Natl Acad Sci U S A 2000;97:10032-10037

62. Takahashi-Yanaga F, Kahn M. Targeting Wnt signaling: can we safely eradicate cancer stem cells? Clin Cancer Res 2010;16:3153-3162

63. Takezaki T, Hide T, Takanaga H, Nakamura H, Kuratsu J, Kondo T. Essential role of the Hedgehog signaling pathway in human glioma-initiating cells. Cancer Sci 2011;102: 1306-1312

64. Prince ME, Sivanandan R, Kaczorowski A, Wolf GT, Kaplan MJ, Dalerba P, Weissman IL, Clarke MF, Ailles LE. Identification of a subpopulation of cells with cancer stem cell properties in head and neck squamous cell carcinoma. Proc Natl Acad Sci U S A 2007;104:973-978

65. Zhao Y, Bao Q, Renner A, Camaj P, Eichhorn M, Ischenko I, Angele M, Kleespies A, Jauch KW, Bruns C. Cancer stem cells and angiogenesis. Int J Dev Biol 2011;55:477-482

66. Calabrese C, Poppleton H, Kocak M, Hogg TL, Fuller C, Hamner B, Oh EY, Gaber MW, Finklestein D, Allen M, Frank A, Bayazitov IT, Zakharenko SS, Gajjar A, Davidoff A, Gilbertson RJ. A perivascular niche for brain tumor stem cells. Cancer Cell 2007;11:69-82

67. Pàez-Ribes $M$, Allen $E$, Hudock J, Takeda T, Okuyama $H$, Viñals F, Inoue M, Bergers G, Hanahan D, Casanovas O. Antiangiogenic therapy elicits malignant progression of tumors to increased local invasion and distant metastasis. Cancer Cell 2009;15:220-231

68. Tang C, Ang BT, Pervaiz S. Cancer stem cell: target for anti-cancer therapy. FASEB J 2007;21:3777-3785 